\title{
In Vitro Antimicrobial and Modulatory Activity of the Natural Products Silymarin and Silibinin
}

\author{
Dayanne Rakelly de Oliveira, ${ }^{1}$ Saulo Relison Tintino, ${ }^{2}$ \\ Maria Flaviana Bezerra Morais Braga, ${ }^{2}$ Aline Augusti Boligon, ${ }^{3}$ \\ Margareth Linde Athayde, ${ }^{3}$ Henrique Douglas Melo Coutinho, ${ }^{2}$ \\ Irwin Rose Alencar de Menezes, ${ }^{4}$ and Roselei Fachinetto ${ }^{1,5}$ \\ ${ }^{1}$ Programa de Pós-Graduação em Ciências Biológicas, Bioquímica Toxicológica, Universidade Federal de Santa Maria, \\ 97105-700 Santa Maria, RS, Brazil \\ ${ }^{2}$ Laboratório de Microbiologia e Biologia Molecular, Universidade Regional do Cariri (URCA), 63100-000 Crato, CE, Brazil \\ ${ }^{3}$ Departamento de Farmácia Industrial, Universidade Federal de Santa Maria, 97105-700 Santa Maria, RS, Brazil \\ ${ }^{4}$ Laboratório de Microbiologia e Biologia Molecular, Departamento de Química Biológica, Universidade Regional do Cariri, \\ 63100-000 Crato,CE, Brazil \\ ${ }^{5}$ Programa de Pós-Graduaçãoo em Farmacologia, Universidade Federal de Santa Maria, 97105-700 Santa Maria, RS, Brazil \\ Correspondence should be addressed to Henrique Douglas Melo Coutinho; hdmcoutinho@gmail.com
}

Received 26 September 2014; Revised 12 February 2015; Accepted 15 February 2015

Academic Editor: Glen Jickling

Copyright ( 2015 Dayanne Rakelly de Oliveira et al. This is an open access article distributed under the Creative Commons Attribution License, which permits unrestricted use, distribution, and reproduction in any medium, provided the original work is properly cited.

\begin{abstract}
Silymarin is a standardized extract from the dried seeds of the milk thistle (Silybum marianum L. Gaertn.) clinically used as an antihepatotoxic agent. The aim of this study was to investigate the antibacterial and antifungal activity of silymarin and its major constituent (silibinin) against different microbial strains and their modulatory effect on drugs utilized in clinical practice. Silymarin demonstrated antimicrobial activity of little significance against the bacterial strains tested, with MIC (minimum inhibitory concentration) values of $512 \mu \mathrm{g} / \mathrm{mL}$. Meanwhile, silibinin showed significant activity against Escherichia coli with a MIC of $64 \mu \mathrm{g} / \mathrm{mL}$. The results for the antifungal activity of silymarin and silibinin demonstrated a MIC of $1024 \mu \mathrm{g} / \mathrm{mL}$ for all strains. Silymarin and silibinin appear to have promising potential, showing synergistic properties when combined with antibacterial drugs, which should prompt further studies along this line.
\end{abstract}

\section{Introduction}

Microbial infections have become one of the principal problems of public health in the world, affecting all countries, developing or developed. It can be related to the process of natural selection in bacterial development or the natural consequence of the adaptation of bacteria to exposure to antibiotics in the course of the indiscriminate use of antibiotics in humans and animals. Various cases related to resistance have been reported, including methicillin-resistant Staphylococcus aureus (MRSA) [1], penicillin-nonsusceptible Streptococcus pneumoniae (PNSSP), vancomycin-resistant enterococci (VRE), extended spectrum beta-lactamase(ESBL-) producing Enterobacteriaceae, and Candida $s p$ resistant to imidazoles.

Staphylococcus aureus is a common cause of cutaneous and soft tissue infections, as well as invasive illness, such as bacteremia, septic arthritis, osteomyelitis, and necrotizing pneumonia [2,3]. Escherichia coli is a Gram-negative bacillus that causes infections, especially neonatal, such as meningitis and septicemia, and even diarrheal diseases, in the whole world, particularly affecting children up to 5 years old. E. coli is typical of the intestinal flora and commensal of the vaginal flora $[4,5]$. Also, Pseudomonas aeruginosa has often 
been associated with occurrence of hospital infections and antibiotic resistance events [6,7].

Microbial resistance is thus problematic for public health, especially coupled to virulence potential of these multiresistant pathogens. Accordingly, we should emphasize the relevance of the discovery of new drugs with antimicrobial capacity and/or showing synergism with drugs already employed in clinical practice [8]. Thus, in the last years, there has been increased use of plants and their derivatives as an alternative modality in the treatment of various diseases, including infections caused by microorganisms [9].

Infections by yeasts of Candida occur on cutaneous and mucosal surfaces, but, in some cases, they become severe by causing systemic infection, especially in immunocompromised patients. Moreover, therapeutic options are still limited, particularly in treating resistant pathogens [10]. Additionally, the indiscriminate use of broad spectrum antibiotics has contributed to the development of fungal infections [11].

Silymarin is a standardized extract from the dried seeds of the milk thistle (Silybum marianum L. Gaertn.), family Asteraceae [12]. Silymarin contains approximately $70-80 \%$ flavonolignans and $20-30 \%$ nonidentified oxidized polyphenolic compounds fraction. The mixture of flavonolignans consists mainly of silybin (silibinin), the major bioactive component of the extract, and isomeric isosilybin, silychristin, and silydianin and two flavonoids (taxifolin and quercetin) $[13,14]$. Silibinin currently is recommended for use in alcoholic liver disease. Ethanol induces free radical formation through multiple pathways, resulting in steatohepatitis and cirrhosis with chronic use $[15,16]$.

Silymarin has clinical use as antihepatotoxic agent [17], has anti-inflammatory properties [18], and is antitumor [19], antifibrotic, and cytoprotective [20]. Studies have reported the synergistic activity of silibinin when combined with ampicillin and gentamicin against bacteria that attack the oral cavity [21]. However, there are few works that have evaluated the antimicrobial capacity of silymarin and silibinin, demonstrating the need to extend the study of their therapeutic use in this regard.

The objective of this work was to investigate silymarin and its major component, silibinin, for possible antimicrobial effects and drug-modifying activity when combined with antibacterial and antifungal drugs commonly used in the clinic and also to compare the activity of the two agents.

\section{Materials and Methods}

2.1. Quantification of Compounds by HPLC-DAD. Reverse phase chromatographic analyses were carried out under gradient conditions using $\mathrm{C}_{18}$ column $(4.6 \mathrm{~mm} \times 250 \mathrm{~mm})$ packed with $5 \mu \mathrm{m}$ diameter particles. The mobile phase was water containing $1 \%$ formic acid (A) and methanol (B), and the composition gradient was $15 \%$ of $\mathrm{B}$ for $10 \mathrm{~min}$ and was changed to obtain $20 \%, 30 \%, 50 \%, 60 \%, 70 \%, 20 \%$, and $10 \%$ $\mathrm{B}$ at $20,30,40,50,60,70$, and $80 \mathrm{~min}$, respectively, following the method described by Boligon et al. [22] with slight modifications. Silymarin extract was analyzed at a concentration of $2.4 \mathrm{mg} / \mathrm{mL}$; the identification of silybin (A and B), gallic acid, and caffeic acid was performed by comparing their retention time and UV absorption spectrum with those of the commercial standards. The flow rate was $0.6 \mathrm{~mL} / \mathrm{min}$, the injection volume was $40 \mu \mathrm{L}$, and the wavelength was $254 \mathrm{~nm}$ for gallic acid, $280 \mathrm{~nm}$ for silybin (A and B), and $327 \mathrm{~nm}$ for caffeic acid. All the samples and mobile phase were filtered through $0.45 \mu \mathrm{m}$ membrane filter (Millipore) and then degassed by ultrasonic bath prior to use. A stock solution of standards references was prepared in the HPLC mobile phase at a concentration range of $0.030-0.250 \mathrm{mg} / \mathrm{mL}$. The chromatography peaks were confirmed by comparing DAD (Diode Array Detector) retention time with those of reference standard and by DAD spectra (200 to $500 \mathrm{~nm}$ ). Calibration curve for gallic acid is $Y=11945+1268.4(r=0.9997)$, for caffeic acid is $Y=13407+1361.8(r=0.9992)$, for silybin A is $Y=12683+1185.9(r=0.9999)$, and for silybin B is $Y=13045 \mathrm{x}$ $+1376.1(r=0.9995)$. All chromatography operations were carried out at ambient temperature and in triplicate. The limit of detection (LOD) and limit of quantification (LOQ) were calculated based on the standard deviation of the responses and the slope using three independent analytical curves. LOD and LOQ were calculated as 3.3 and $10 \sigma / S$, respectively, where $\sigma$ is the standard deviation of the response and $S$ is the slope of the calibration curve.

2.2. Preparation of Stock Solution and Test Solutions. Stock solutions of silymarin and silibinin were prepared at a concentration of $10 \mathrm{mg} / \mathrm{mL}$ in $1 \mathrm{~mL}$ of dimethylsulfoxide (DMSO). Using this concentration, the compounds were diluted in $1 \mathrm{~mL}$ of sterile distilled water to obtain a concentration of $1024 \mu \mathrm{g} / \mathrm{mL}$ (test solution).

2.3. Fungal and Bacterial Strains. The minimal inhibitory concentration (MIC) of silymarin and silibinin was determined using the bacterial strains Escherichia coli 25922, Staphylococcus aureus 25923, and Pseudomonas aeruginosa 9027 and the fungal strains Candida albicans 62, C. krusei 02, and C. tropicalis 20. All strains were obtained from the Clinical Mycology Laboratory of the Federal University of Paraiba. In the antibiotic-modifying assays, we used the multiresistant bacterial strains from the clinical isolates Pseudomonas aeruginosa 03, Escherichia coli 06, and Staphylococcus aureus 10 and the standard yeasts Candida albicans, INCQS 40006, C. krusei, INCQS 40095, and C. tropicalis, INCQS 400042.

We utilized the following culture media for bacteria: heart infusion agar (HIA; Difco Laboratories Ltda.) and brain heart infusion broth (BHI at $10 \%$ as indicated by the manufacturer; Acumedia Manufacturers Inc.). Sabouraud dextrose broth was used for fungi. All culture media were prepared following the manufacturer's instructions. Fungal and bacterial cultures were maintained at $4^{\circ} \mathrm{C}$ in HIA. Before the tests, the strains were passaged using the above media and incubated at $37^{\circ} \mathrm{C}$ for $24 \mathrm{~h}$. The plated strains were inoculated into BHI broth and again incubated at $37^{\circ} \mathrm{C}$ for $24 \mathrm{~h}$. A small aliquot of the cultivated inoculum was removed and diluted in sterile saline to give turbidity equivalent to 0.5 on the McFarland scale, corresponding to $10^{5} \mathrm{CFU} / \mathrm{mL}$ [23]. The resistance profile and origin of the bacterial strains are described in Table 1. 
TABLE 1: Origin of bacterial strains and their resistance to antibiotics.

\begin{tabular}{lll}
\hline Bacteria & Origin & Resistance profile \\
\hline Escherichia coli 06 & Surgical wound & $\begin{array}{l}\text { Aztreonam, Amoxicillin, Ampicillin, Ampicillin, Amoxicillin, Cefadroxil, Cefaclor, } \\
\text { Cephalothin, Ceftazidime, Ciprofloxacin, Chloramphenicol, Imipenem, } \\
\text { Kanamycin, Sulphametrim, Tetracycline, and Tobramycin }\end{array}$ \\
\hline Pseudomonas aeruginosa 03 & Urine culture & $\begin{array}{l}\text { Ceftazidime, Imipenem, Ciprofloxacin, Piperacillin-Tazobactam, Levofloxacin, } \\
\text { Meropenem, and Ampicillin }\end{array}$ \\
\hline Staphylococcus aureus 10 & Surgical wound & $\begin{array}{l}\text { Oxacillin, Gentamicin, Tobramycin, Ampicillin, Kanamycin, Neomycin, } \\
\text { Paromomycin, Butirosin, Sisomicin, and Netilmicin }\end{array}$ \\
\hline
\end{tabular}

2.4. Drugs. The antibacterial drugs utilized were amikacin, gentamicin, ciprofloxacin, and imipenem/cilastatin sodium, and the antifungals employed were mebendazole and nystatin (Sigma Co., St. Louis, USA), at an initial concentration of $2500 \mu \mathrm{g} / \mathrm{mL}$ and $1024 \mu \mathrm{g} / \mathrm{mL}$, respectively. All drugs were dissolved in sterile water. Silymarin powder was obtained commercially from DEG importation (Santa Maria, Brazil). Silibinin was obtained from Sigma Co. The reagent sodium resazurin was utilized as the indicator of bacterial growth; it was also obtained from Sigma Co. and stored at $4^{\circ} \mathrm{C}$ away from light. In reading the assay, a color change from blue to pink due to the reduction of resazurin indicated bacterial growth [24].

\subsection{Determination of Minimal Inhibitory Concentration} (MIC). Antimicrobial activity of the assayed products was determined by the microdilution assay. A volume of $100 \mu \mathrm{L}$ of $10 \%$ BHI medium was added to each well of a 96 -well microplate and $100 \mu \mathrm{L}$ of the test product was used to do a twofold serial dilution giving concentrations of 512 to $8 \mu \mathrm{g} / \mathrm{mL}$. Next, $100 \mu \mathrm{L}$ of the bacterial or yeast suspension was added to all wells except the negative control or blank. The negative control contained $100 \mu \mathrm{L}$ of $10 \%$ BHI medium and $100 \mu \mathrm{L}$ of test product. Meanwhile, the positive control contained the bacterial or yeast suspension and $10 \%$ BHI. The plates were placed in an incubator for $24 \mathrm{~h}$ at $37^{\circ} \mathrm{C}$ [25]. Bacterial growth was determined utilizing resazurin, while fungal growth was evaluated according to turbidity. The assays were done in triplicate. MIC was defined as the lowest concentration at which no growth was observed in accordance with NCCLS [23].

2.6. Test for Antibiotic-Modifying Activity. Silymarin and silibinin were tested for possible antibiotic-modifying activity by their combination with the antibacterial and antifungal drugs listed above, according to the method proposed by Coutinho et al. [26], where the test products were used at a subinhibitory concentration (MIC/8).

2.7. Statistical Analysis. Each experiment was performed six times and the results were normalized by calculation of geometric mean values. Error deviation and standard deviation of the geometric mean were revealed. Statistical analyses were performed using GraphPad Prism, version 5.02. Differences between treatment with antibiotics in the absence and in the presence of the products were examined
TABLE 2: Composition of Silymarin extract.

\begin{tabular}{lccc}
\hline Compounds & $\begin{array}{c}\text { Silymarin } \\
\mathrm{mg} / \mathrm{g}\end{array}$ & $\begin{array}{c}\text { LOD } \\
\mu \mathrm{g} / \mathrm{mL}\end{array}$ & $\begin{array}{c}\text { LOQ } \\
\mu \mathrm{g} / \mathrm{mL}\end{array}$ \\
\hline Gallic acid & $2.16 \pm 0.01^{\mathrm{a}}$ & 0.009 & 0.029 \\
\hline Caffeic acid & $5.09 \pm 0.03^{\mathrm{b}}$ & 0.032 & 0.105 \\
\hline Silybin A & $12.75 \pm 0.01^{\mathrm{c}}$ & 0.011 & 0.034 \\
Silybin B & $15.93 \pm 0.03^{\mathrm{d}}$ & 0.027 & 0.89 \\
\hline
\end{tabular}

Results are expressed as mean \pm standard deviations (SD) of three determinations.

Averages followed by different letters differ by Tukey's test at $P<0.05$.

using two-way analysis of variance (ANOVA). The differences mentioned above were analyzed by Bonferroni posttest and they were considered statistically significant when $P<0.05$.

\section{Results}

3.1. HPLC Analysis. HPLC fingerprinting of silymarin extract revealed the presence of gallic acid $\left(t_{R}=10.19 \mathrm{~min}\right.$; peak 1$)$, caffeic acid $\left(t_{R}=24.97\right.$ min; peak 2$)$, silybin A $\left(t_{R}=42.17 \mathrm{~min}\right.$; peak 3$)$, and silybin B $\left(t_{R}=45.89 \mathrm{~min}\right.$; peak 4$)$. Calibration curve for gallic acid is $Y=11945+1268.4(r=0.9997)$, for caffeic acid is $Y=13407+1361.8(r=0.9992)$, for silybin A is $Y=12683+1185.9(r=0.9999)$, and for silybin B is $Y=$ $13045 \mathrm{x}+1376.1(r=0.9995)$ (Table 2; Figure 1).

\subsection{Antibacterial Activity and Modulation of Antibiotic Activ-} ity by Silymarin Extract and Silibinin. Silymarin demonstrated antimicrobial activity that was clinically irrelevant, with MIC values of $512 \mu \mathrm{g} / \mathrm{mL}$. The results demonstrating the modulatory antibiotic activity of silymarin and silibinin are demonstrated in Figures 2-4 and the silymarin at a concentration of $64 \mu \mathrm{g} / \mathrm{mL}$ was combined with the antibiotics. Silibinin showed a MIC of $1024 \mu \mathrm{g} / \mathrm{mL}$ and was thus clinically irrelevant for the strains Staphylococcus aureus ATCC 25923 and Pseudomonas aeruginosa ATCC 9027, so a concentration of $128 \mu \mathrm{g} / \mathrm{mL}$ was used in drug-modifying assays. However, for Escherichia coli ATCC 25922, the MIC was $64 \mu \mathrm{g} / \mathrm{mL}$, and thus, a concentration of $8 \mu \mathrm{g} / \mathrm{mL}$ was used in drug-modifying assays.

Silymarin and silibinin demonstrated antifungal activity with MIC value of $1024 \mu \mathrm{g} / \mathrm{mL}$ for all strains, and thus, a concentration of $128 \mu \mathrm{g} / \mathrm{mL}$ was used for both products to evaluate antibiotic-modifying activity. 


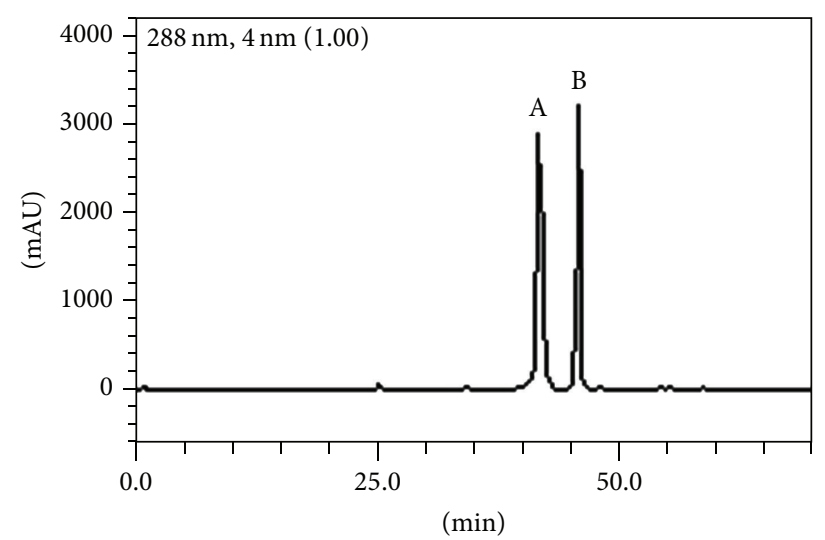

(a)

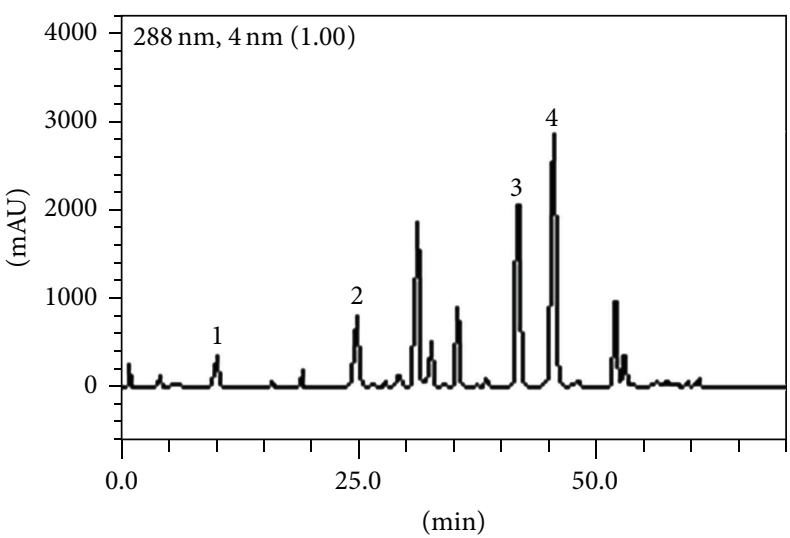

(b)

FIGURE 1: Representative high performance liquid chromatography profile of Silymarin, detection UV was at $288 \mathrm{~nm}$. Gallic acid (peak 1), caffeic acid (peak 2), silybin A (peak 3), and silybin B (peak 4) ((a) and (b)).

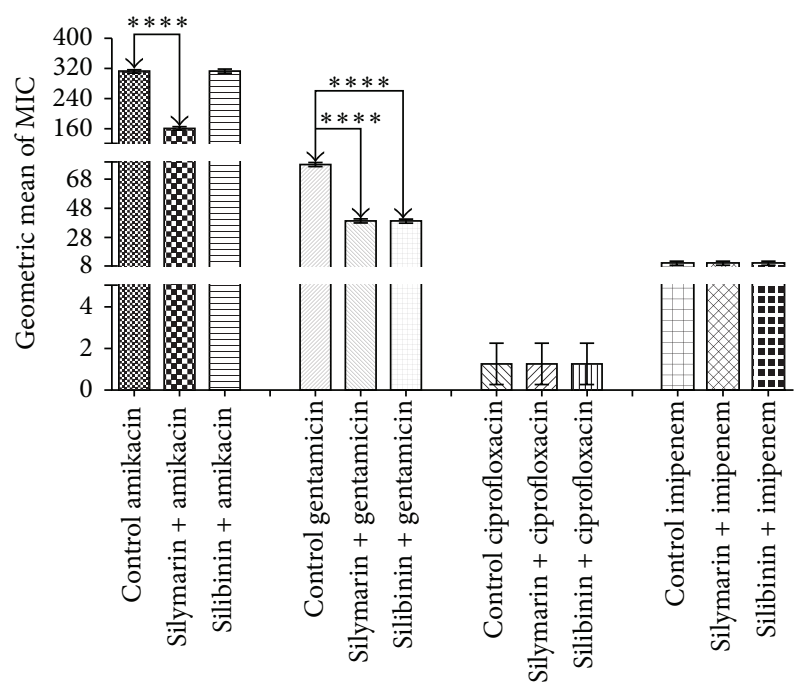

Figure 2: MIC $(\mu \mathrm{g} / \mathrm{mL})$ of the antibiotics in the absence and presence of silymarin and silibinin at subinhibitory concentrations for E. coli strain EC06.

Silymarin demonstrated significant synergistic activity in modulating the effect of aminoglycosides against $E$. coli $(P<$ 0.001 ), reducing the MIC from 312.5 to $156.25 \mu \mathrm{g} / \mathrm{mL}$ for amikacin and from 78.125 to $39.06 \mu \mathrm{g} / \mathrm{mL}$ for gentamicin. Silibinin showed similar synergism when combined with gentamicin $(P<0.001)$, lowering the MIC from 78.125 to $39.06 \mu \mathrm{g} / \mathrm{mL}$ when compared to the control. Silymarin and silibinin showed significant synergism in the presence of the antibiotics amikacin with a reduction in MIC from 78.125 to $39.06 \mu \mathrm{g} / \mathrm{mL}(P<0.001)$ and ciprofloxacin with a reduction in MIC from 78.125 to $39.06 \mu \mathrm{g} / \mathrm{mL}(P<0.001)$ against $P$. aeruginosa compared to the control. Silymarin also demonstrated a significant synergistic effect when combined with gentamicin lowering the MIC from 156.25 to $78.125 \mu \mathrm{g} / \mathrm{mL}$ $(P<0.001)$ in relation to the control.

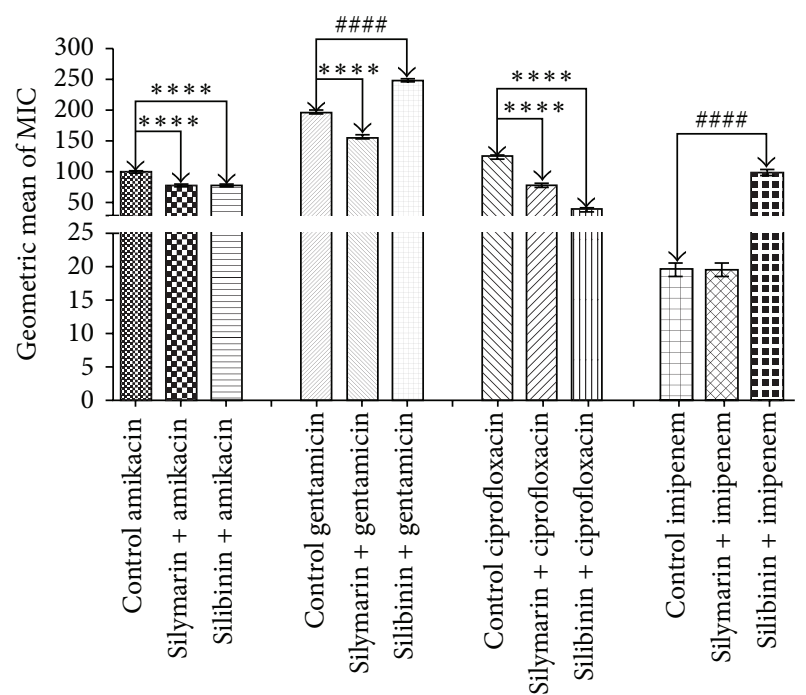

FIGURE 3: MIC $(\mu \mathrm{g} / \mathrm{mL})$ of the antibiotics in the absence and presence of silymarin and silibinin at subinhibitory concentrations for $P$. aeruginosa strain PA03.

It is important to mention that silibinin showed an antagonistic effect when combined with gentamicin and imipenem. But against $S$. aureus, silymarin and silibinin displayed substantial synergistic activity when combined with the antibiotics amikacin, reducing the MIC from 19.53 to $1.22 \mu \mathrm{g} / \mathrm{mL}$ $(P<0.001)$, gentamicin, lowering the MIC from 19.53 to $9.76 \mu \mathrm{g} / \mathrm{mL}(P<0.001)$, and imipenem, reducing the MIC from 39.06 to $2.44 \mu \mathrm{g} / \mathrm{mL}(P<0.001)$, compared to the control.

The results demonstrating the modulatory effect against antifungal drugs were demonstrated in Figures 5 and 6 . The antifungal modulatory activity of the products tested indicated an antagonistic effect against C. albicans, C. tropicalis, and C. krusei, when compared to nystatin and no significant effect in combination with mebendazole. 


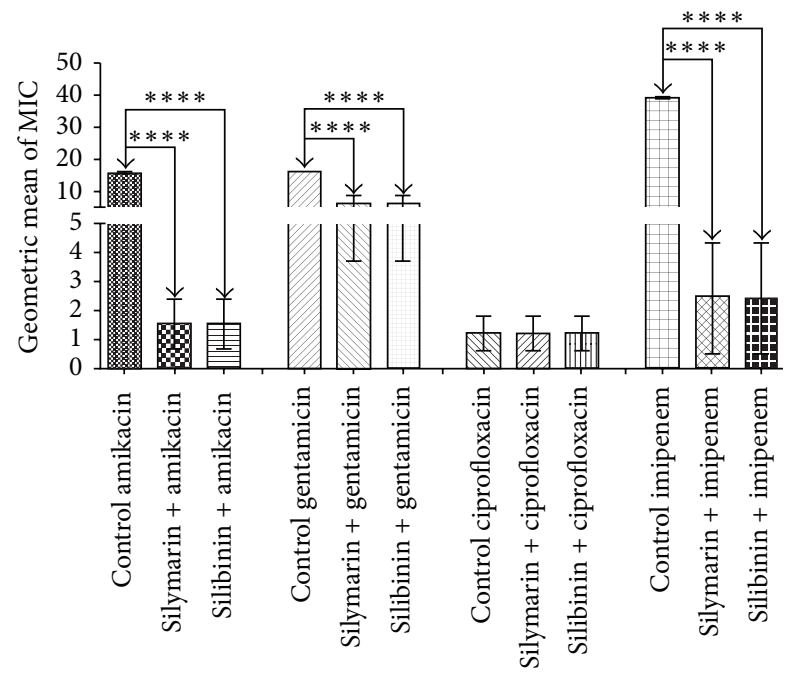

Figure 4: MIC $(\mu \mathrm{g} / \mathrm{mL})$ of the antibiotics in the absence and presence of silymarin and silibinin at subinhibitory concentrations for $S$. aureus strain SA10.

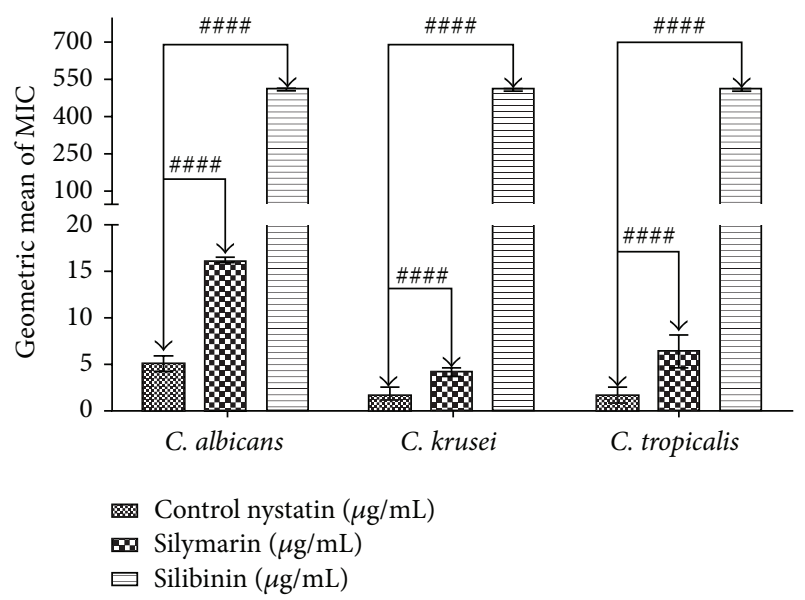

Figure 5: MIC $(\mu \mathrm{g} / \mathrm{mL})$ of nystatin in the absence and presence of silymarin and silibinin at subinhibitory concentrations for $C$. albicans, C. tropicalis, and C. krusei.

\section{Discussion}

Infections caused by pathogens such as $P$. aeruginosa, $S$. aureus, E. coli, and C. albicans have a high prevalence, where they are responsible for the increase in worldwide morbimortality of infections [27]. Factors involved in this increase vary from insufficient supply of antimicrobials, especially in poorer countries, to occurrence of antibiotic resistance. Thus, in the last decades, there has been an increase in the popular use of plants and their derivatives for infections caused by microorganisms [28].

Various studies on the evaluation of the antimicrobial activity of natural products have been conducted with the aim of broadening the spectrum of antimicrobial therapy. However, it is important to mention that the microdilution

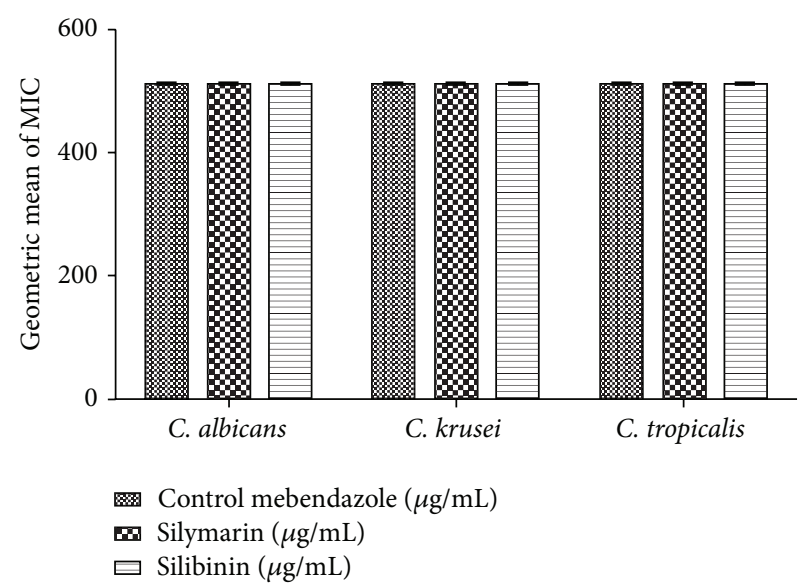

FIgURE 6: MIC $(\mu \mathrm{g} / \mathrm{mL})$ of the mebendazole in the absence and presence of silymarin and silibinin at subinhibitory concentrations for C. albicans, C. tropicalis, and C. krusei.

method, employed in the present investigation, currently represents the technique most accepted for this bioassay [29].

Silybum marianum (L.) Gaertn. (Carduus marianus L. Asteraceae) (milk thistle) has been used for more than 2000 years to treat liver and gallbladder disorders, including hepatitis, cirrhosis, and jaundice, and to protect the liver against poisoning from chemical and environmental toxins [12]. Silymarin is an active component of this plant, a standardized extract obtained from the seeds of $S$. marianum containing approximately 70 to $80 \%$ of the silymarin flavonolignans and approximately 20 to $30 \%$ is chemically undefined fraction, comprising mostly polymeric and oxidized polyphenolics compounds [30]. Silibinin is a major bioactive component of silymarin [13].

The incidence of studies investigating the biological activities of silymarin and silibinin has increased, given the variety of important pharmacological effects associated with these compounds, together with the fact that the use of silymarin/silibinin is considered safe, where there have been few reports of adverse effects [31,32]. Recent in vivo and in vitro studies have demonstrated that silibinin has antioxidant, antiinflammatory, antitumor, and antiarthritic properties [31]. Also, silibinin has shown antibacterial activity against the Gram-positive bacteria Bacillus subtilis and Staphylococcus epidermidis [33].

Findings have pointed to a synergistic drug-modifying effect when silymarin and silibinin were combined with antibiotics, especially aminoglycosides, against the different bacterial strains evaluated, where silibinin had an antagonistic effect when combined with imipenem and gentamicin against $P$. aeruginosa. Accordingly, phenolic compounds, for example, flavonoids and lignans, have demonstrated their therapeutic potential as antimicrobial agents, where they are considered responsible for this activity $[34,35]$. The synergistic effect of flavonoids combined with commonly utilized antibiotics is well supported in the literature, emerging as an important complementary treatment modality in research [36]. 
It is believed, therefore, that phenolic compounds possess the capacity to form complexes with extracellular soluble proteins that bind to bacterial cell wall [37]. Studies have shown that many natural compounds alter the permeability of the cell membrane, favoring the penetration of antibiotics [38]. The interaction with bacterial enzymes can also be related to the synergistic mechanism of natural products with antibiotics [39], which can be obtained from an extract or from the combination of extracts, synthetic products, antibiotics, and other natural products [40, 41].

With respect to the antibacterial action of flavonoids, studies have demonstrated a significant inhibitory effect on DNA topoisomerase activity by the formation of complexes that alter enzyme binding [42]. In this perspective, the antibacterial activity of these compounds could also be related to the presence of hydroxyl phenolic groups that interfere with the bacterial synthetic processes by enzyme inhibition $[43,44]$.

Our results pointed to an antagonistic effect when silymarin and silibinin were combined with nystatin against the yeasts $C$. albicans, $C$ tropicalis, and C. krusei. This result was probably due to the cell structure of the fungi, mainly the chitin cell wall of these microorganisms, which apparently affects the action of antifungal agents and drug-modifying activity of natural products. However, new studies are needed to determine how this occurs. Considering the growing use of antifungal agents in cancer treatment and infectious diseases in general, these agents have contributed to the increase in drug resistance, leading to the need to discover new and alternative treatment modalities [45]. Thus, plant species rich in active metabolites such as flavonoids merit attention [46].

\section{Conclusions}

This work indicates the possibility of the usage of silymarin and silibinin as a source of new drugs as adjuvants in the antibiotic therapy against multidrug resistant bacteria (MDR), being a promising choice against the concerning problem of the antibiotic resistance.

\section{Conflict of Interests}

The authors declare that there is no conflict of interests regarding the publication of this paper.

\section{Acknowledgments}

The authors are grateful to the Brazilian research agencies CNPq, CAPES, and FUNCAP for the funding of this work.

\section{References}

[1] S. Gibbons, "Anti-staphylococcal plant natural products," Natural Product Reports, vol. 21, no. 2, pp. 263-277, 2004.

[2] M. Otto, "Basis of virulence in community-associated methicillin-resistant Staphylococcus aureus," Annual Review of Microbiology, vol. 64, pp. 143-162, 2010.
[3] P. Seymour and J. Golding, "Hospital-acquired and communityacquired MRSA: two distinct infections," Emergency Medicine, vol. 41, no. 10, pp. 36-41, 2009.

[4] S. Watt, P. Lanotte, L. Mereghetti, M. Moulin-Schouleur, B. Picard, and R. Quentin, "Escherichia coli strains from pregnant women and neonates: intraspecies genetic distribution and prevalence of virulence factors," Journal of Clinical Microbiology, vol. 41, no. 5, pp. 1929-1935, 2003.

[5] R. L. Vogt and L. Dippold, "Escherichia coli O157:H7 outbreak associated with consumption of ground beef, June-July 2002," Public Health Reports, vol. 120, no. 2, pp. 174-178, 2005.

[6] C. van Delden and B. H. Iglewski, "Cell-to-cell signaling and Pseudomonas aeruginosa infections," Emerging Infectious Diseases, vol. 4, no. 4, pp. 551-560, 1998.

[7] E. J. Muñoz-Elías and J. D. McKinney, "Bacterial persistence: strategies for survival," in Immunology of Infectious Diseases, S. H. E. Kaufmann, A. Sher, and R. Ahmed, Eds., pp. 331-355, ASM Press, Washington, DC, USA, 2002.

[8] R. C. Moellering, "Novos desafios no campo das doenças infecciosas," in Patógenos Emergentes nas Doenças Infecciosas: Relatório Especial Hospital Práctice, Euromédice, Edições Médicas, Oeiras, Portugal, 2000.

[9] I. F. Silva Jr., V. C. Filho, S. A. Zacchino, J. C. D. S. Lima, and D. T. D. O. Martins, "Antimicrobial screening of some medicinal plants from Mato Grosso Cerrado," Brazilian Journal of Pharmacognosy, vol. 19, no. 1, pp. 242-248, 2009.

[10] Z. A. Kanafani and J. R. Perfect, "Resistance to antifungal agents: mechanisms and clinical impact," Clinical Infectious Diseases, vol. 46, no. 1, pp. 120-128, 2008.

[11] R. S. Almeida, Micologia, Ciências Farmacêuticas, Rio de Janeiro, Brazil, 2008.

[12] P. Morazzoni and E. Bombardelli, "Silybum marianum (Carduus marianus)," Fitoterapia, vol. 66, no. 1, pp. 3-42, 1995.

[13] C. Loguercio and D. Festi, "Silybin and the liver: from basic research to clinical practice," World Journal of Gastroenterology, vol. 17, no. 18, pp. 2288-2301, 2011.

[14] H. Wagner, L. Hörhammer, and R. Münster, "On the chemistry of silymarin (silybin), the active principle of the fruits from Silybum marianum (L.) Gaertn. (Carduus marianus L.)," Arzneimittel-Forschung/Drug Research, vol. 18, no. 6, pp. 688696, 1968.

[15] C. Nencini, G. Giorgi, and L. Micheli, "Protective effect of silymarin on oxidative stress in rat brain," Phytomedicine, vol. 14, no. 2-3, pp. 129-135, 2007.

[16] A. Valenzuela and R. Guerra, "Protective effect of the flavonoid silybin dihemisuccinate on the toxicity of phenylhydrazine on rat liver," FEBS Letters, vol. 181, no. 2, pp. 291-294, 1985.

[17] R. Saller, R. Meier, and R. Brignoli, "The use of silymarin in the treatment of liver diseases," Drugs, vol. 61, no. 14, pp. 2035-2063, 2001.

[18] A. Miadonna, A. Tedeschi, E. Leggieri, M. Lorini, M. Froldi, and C. Zanussi, "Effects of silybin on histamine release from human basophil leucocytes," British Journal of Clinical Pharmacology, vol. 24, no. 6, pp. 747-752, 1987.

[19] S. K. Katiyar, N. J. Korman, H. Mukhtar, and R. Agarwal, "Protective effects of silymarin against photocarcinogenesis in a mouse skin model," Journal of the National Cancer Institute, vol. 89, no. 8, pp. 556-566, 1997.

[20] G. Boigk, L. Stroedter, H. Herbst, J. Waldschmidt, E. O. Riecken, and D. Schuppan, "Silymarin retards collagen accumulation in early and advanced biliary fibrosis secondary to complete bile 
duct obliteration in rats," Hepatology, vol. 26, no. 3, pp. 643-649, 1997.

[21] Y.-S. Lee, K.-A. Jang, and J.-D. Cha, "Synergistic antibacterial effect between silibinin and antibiotics in oral bacteria," Journal of Biomedicine and Biotechnology, vol. 2012, Article ID 618081, 7 pages, 2012.

[22] A. A. Boligon, T. G. Schwanz, M. Piana et al., "Chemical composition and antioxidant activity of the essential oil of Tabernaemontana catharinensis A. DC. leaves," Natural Product Research, vol. 27, no. 1, pp. 68-71, 2013.

[23] NCCLS-National Comitte for CLinical Laboratory Standards, Methods for Dilution Antimicrobial Susceptibility Testes for Bacteria That Grow Aerobically, vol. 20, NCCLS Approved Standard M7-A5, Villanova, Pa, USA, 6th edition, 2005.

[24] J.-C. Palomino, A. Martin, M. Camacho, H. Guerra, J. Swings, and F. Portaels, "Resazurin microtiter assay plate: simple and inexpensive method for detection of drug resistance in Mycobacterium tuberculosis," Antimicrobial Agents and Chemotherapy, vol. 46, no. 8, pp. 2720-2722, 2002.

[25] M. M. Javadpour, M. M. Juban, W.-C. J. Lo et al., "De novo antimicrobial peptides with low mammalian cell toxicity," Journal of Medicinal Chemistry, vol. 39, no. 16, pp. 3107-3113, 1996.

[26] H. D. M. Coutinho, J. G. M. Costa, V. S. Falcão-Silva, J. P. Siqueira Jr., and E. O. Lima, "Effect of Momordica charantia L. in the resistance to aminoglycosides in methicilin-resistant Staphylococcus aureus," Comparative Immunology, Microbiology and Infectious Disease, vol. 33, no. 6, pp. 467-471, 2010.

[27] V. Kuete, J. Kamga, L. P. Sandjo et al., "Antimicrobial activities of the methanol extract, fractions and compounds from Ficus polita Vahl. (Moraceae)," BMC Complementary and Alternative Medicine, vol. 11, article 6, 2011.

[28] Y. Bibi, S. Nisa, F. M. Chaudhary, and M. Zia, "Antibacterial activity of some selected medicinal plants of Pakistan," BMC Complementary and Alternative Medicine, vol. 11, article 52, 2011.

[29] F. Hadacek and H. Greger, "Testing of antifungal natural products: methodologies, comparability of results and assay choice," Phytochemical Analysis, vol. 11, no. 3, pp. 137-147, 2000.

[30] V. Šimánek, V. Kren, J. Ulrichová, J. Vicar, and L. Cvak, "Silymarin: what is in the name ...? An appeal for a change of editorial policy," Hepatology, vol. 32, no. 2, pp. 442-444, 2000.

[31] V. Křen and D. Walterová, "Silybin and silymarin-new effects and applications," Biomedical Papers, vol. 149, no. 1, pp. 29-41, 2005.

[32] B. P. Jacobs, C. Dennehy, G. Ramirez, J. Sapp, and V. A. Lawrence, "Milk thistle for the treatment of liver disease: a systematic review and meta-analysis," The American Journal of Medicine, vol. 113, no. 6, pp. 506-515, 2002.

[33] G. L. Dong, K. K. Hyung, Y. Park et al., "Gram-positive bacteria specific properties of silybin derived from Silybum marianum," Archives of Pharmacal Research, vol. 26, no. 8, pp. 597-600, 2003.

[34] D. C. Michelin, P. E. Moreschi, A. C. Lima, G. G. F. Nascimento, M. O. Paganelli, and M. V. Chaud, "Avaliação da atividade antimicrobiana de extratos vegetais," Revista Brasileira de Farmacognosia, vol. 15, no. 4, 2005.

[35] J. A. S. Zuanazzi and J. A. Montanha, "Flavonóides," in Farmacognosia: da planta ao medicamento, C. M. O. Simões, E. P. Schenkel, G. Gosmann, J. C. Mello, L. A. Mentz, and P. R. Petrovick, Eds., pp. 577-614, Editora da UFRGS, Porto Alegre, Brazil, 5th edition, 2004.

[36] M. Daglia, "Polyphenols as antimicrobial agents," Current Opinion in Biotechnology, vol. 23, no. 2, pp. 174-181, 2012.
[37] H. Tsuchiya, M. Sato, T. Miyazaki et al., "Comparative study on the antibacterial activity of phytochemical flavanones against methicillin-resistant Staphylococcus aureus," Journal of Ethnopharmacology, vol. 50, no. 1, pp. 27-34, 1996.

[38] S. Burt, "Essential oils: their antibacterial properties and potential applications in foods-a review," International Journal of Food Microbiology, vol. 94, no. 3, pp. 223-253, 2004.

[39] C. N. Wendakoon and M. Sakaguchi, "Inhibition of amino acid decarboxylase activity of Enterobacter aerogenes by active components in spices," Journal of Food Protection, vol. 58, no. 3, pp. 280-283, 1995.

[40] H. N. H. Veras, F. F. G. Rodrigues, A. V. Colares et al., "Synergistic antibiotic activity of volatile compounds from the essential oil of Lippia sidoides and thymol," Fitoterapia, vol. 83, no. 3, pp. 508-512, 2012.

[41] H. D. M. Coutinho, A. Vasconcellos, M. A. Lima, G. G. Almeida-Filho, and R. R. N. Alves, "Termite usage associated with antibiotic therapy: enhancement of aminoglycoside antibiotic activity by natural products of Nasutitermes corniger (Motschulsky 1855)," BMC Complementary and Alternative Medicine, vol. 9, no. 1, article 35, 7 pages, 2009.

[42] Q. Wang, H. Wang, and M. Xie, "Antibacterial mechanism of soybean isoflavone on Staphylococcus aureus," Archives of Microbiology, vol. 192, no. 11, pp. 893-898, 2010.

[43] H. P. Ávila, E. D. F. A. Smânia, F. D. Monache, and A. Smânia, "Structure-activity relationship of antibacterial chalcones," Bioorganic and Medicinal Chemistry, vol. 16, no. 22, pp. 97909794, 2008.

[44] Y. Li, Y. Luo, Y. Hu et al., "Design, synthesis and antimicrobial activities of nitroimidazole derivatives containing 1,3,4oxadiazole scaffold as FabH inhibitors," Bioorganic and Medicinal Chemistry, vol. 20, no. 14, pp. 4316-4322, 2012.

[45] P. M. Salas, G. Céliz, H. Geronazzo, M. Daz, and S. L. Resnik, "Antifungal activity of natural and enzymatically-modified flavonoids isolated from citrus species," Food Chemistry, vol. 124, no. 4, pp. 1411-1415, 2011.

[46] T. Arif, T. K. Mandal, and R. Dabur, "Natural products: antifungal agents derived from plants," in Opportunity, Challenge and Scope of Natural Products in Medicinal Chemistry, vol. 81, pp. 283-311, 2011. 


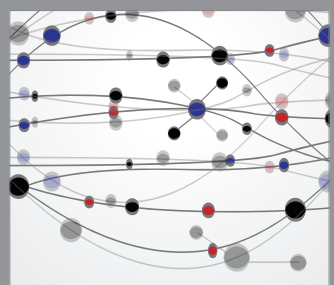

The Scientific World Journal
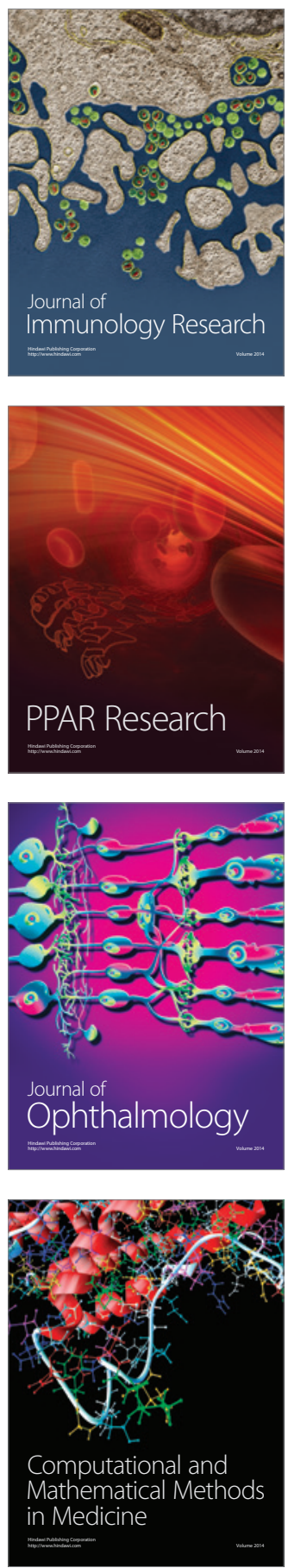

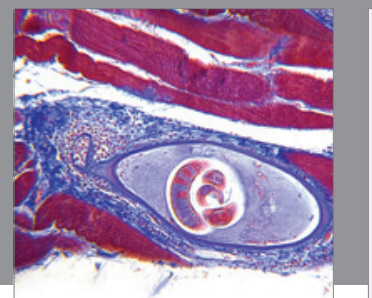

Gastroenterology

Research and Practice
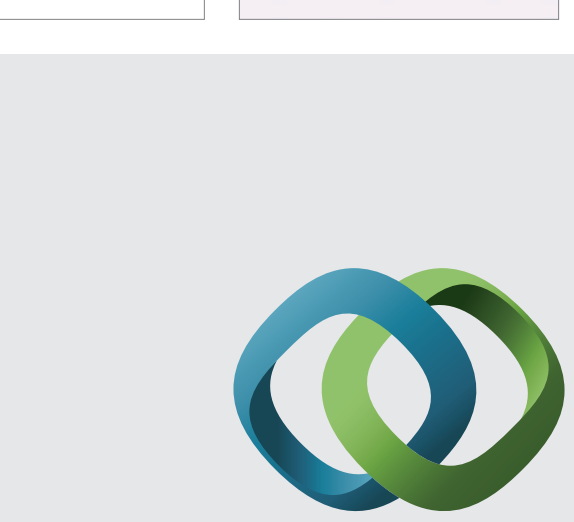

\section{Hindawi}

Submit your manuscripts at

http://www.hindawi.com
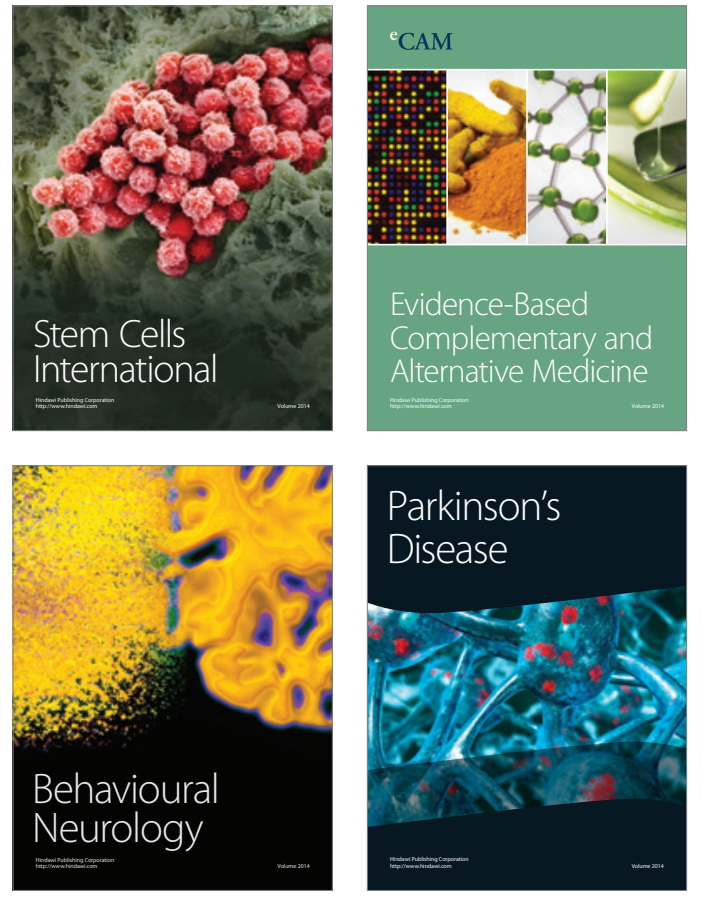
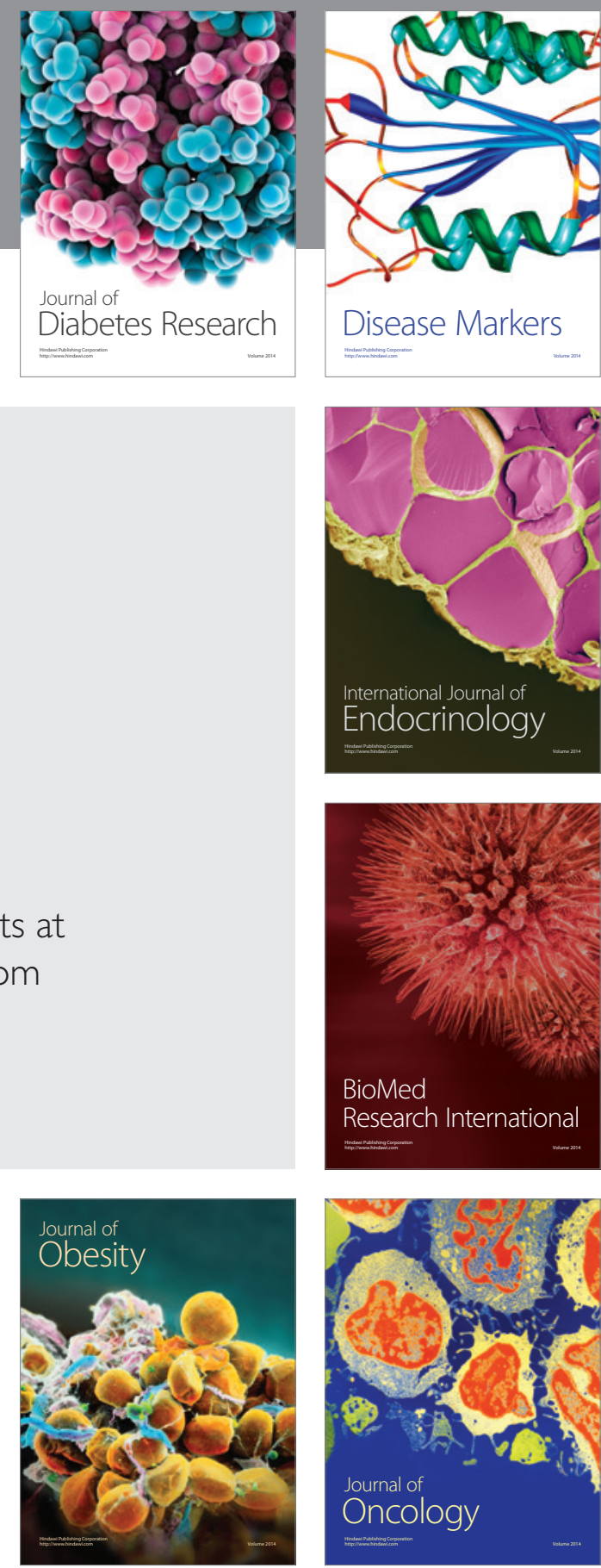

Disease Markers
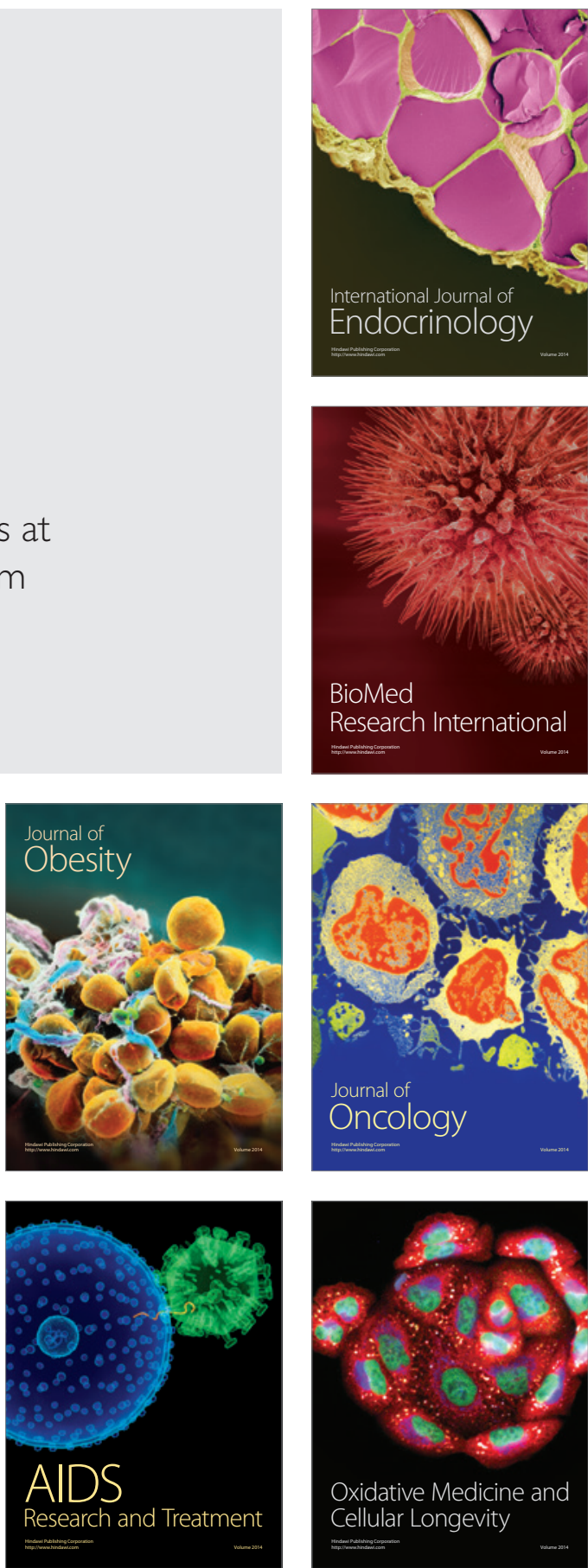